Budkavlen 2020

Gurbet Peker

\title{
Djuren i den rurala livsstilsmigrationen
}

Drömmen om ett liv på landsbygden är ett tydligt samtida uttryck. I TV-program, sociala medier och tidningar återkommer porträtt av familjer som, med kritik mot "urban livsföring", valt att lämna ett vardagsliv i stadsmiljö för att istället leva på en gård med djur (Ulver 2012:12ff). Detta sökande efter ett liv på landsbygden, efter den rurala idyllen, förväntas realisera förhoppningar om ett bättre, enklare, lugnare och mer autentiskt liv (Benson \& O’Reilly 2009a:3f; Osbaldiston 2011:214ff). Denna typ av förflyttningar benämns i föreliggande artikel som rural livsstilsmigration, vilken är en variant av det generella fenomenet livsstilsmigration. Som livsstilsmigrant söker man sig frivilligt, utifrån självrannsakan och reflektion över livssituationen, till en annan plats för ett bättre liv. Livsstilsmigration är pågående självförverkligande projekt med ständig utvärdering av vardagslivets villkor, en utvärdering som fortsätter även efter att den fysiska flytten ägt rum (Benson \& O’Reilly 2009a:1f; Benson \& O’Reilly 2009b:608ff).

Kulturanalytiskt har livsstilsmigration undersökts i olika varianter. Förflyttningar till skånsk landsbygd (Nilsson 2013), svenska bruks-

Nyckelord: Livsstilsmigration, rural idyll, djurhållning, mellanartsliga relationer 
orter (Agnidakis 2013), Varanasi och Goa i Indien (Korpela 2019), Spanska solkusten (Woube 2014) och nordamerikansk landsbygd (Hoey 2009) är några exempel på studerade migrationer. I min etnologiska masteruppsats undersöktes rural livsstilsmigration till Gotland (Peker 2019b), vilket är ett övergripande ämnesområde även för denna artikel. Mellan år 2017 och år 2019 fältarbetade jag på ön i perioder. Jag samtalade med personer som lämnat Stockholm, bosatt sig på en gård och börjat hålla djur på den gotländska landsbygden. I mina samtal med dessa flyttare ${ }^{1}$ visade sig ett ämnesområde vara mer påtagligt och återkommande än andra, nämligen djur och djurhållning. När migranterna beskrev sina motiv till flytten, visade sina gårdar samt berättade om sin nya livsstil, var det främst deras djur och djurhållning som tog plats i samtalen. Även om människors relationer till andra djur är förtjänstfulla utgångspunkter för att undersöka kulturella fenomen (Birke \& Latimer 2009:2f; Löfgren 1984:275ff) och att djuren var så framträdande i berättelserna hos flyttarna, är djurs och djurhållningars betydelser för rural livsstilsmigration tämligen outforskade. Detta bidrog till att de mellanartsliga relationerna blev ett centralt tema för examensarbetet (Peker 2019b). Föreliggande artikel fördjupar och utvecklar analysen av det djurrelaterade materialet.

I artikeln analyseras djurens och djurhålningens betydelser för rural livsstilsmigration. Ett område som undersöks är vilka roller djuren och djurhållningen har i flyttarnas föreställningar om den rurala idyll och plats de söker sig till. Jag skildrar och diskuterar också vilka djurrelaterade vardagliga praktiker och mellanartsliga relationer som utvecklas och levs mellan flyttare och djur. Slutligen görs en sammanfattande analys av hur djuren och djurhållningen påverkar det pågående livsstilsprojekt som den rurala livsstilsmigrationen utgör. Studien fördjupar förståelsen av den rurala livsstilsmigrationen och bidrar även till de fält som kulturvetenskapliga djurstudier utgör. Det finns behov av ytterligare forskning som behandlar djurens roller i hushållens förändringsprocesser, inte minst när det gäller lantbruksrelaterade djur (Doré, Michalon \& Monterio 2019:11). Denna artikel bidrar bland annat till att fylla denna kunskapslucka. 
Artikeln tar sin utgångspunkt i att människor och andra djur är i ständig samtillblivelse (Haraway 2008:16ff). Arter och deras livsvärldar är inte på förhand givna utan blir ständigt till, av och med varandra (Ingold 2013:8ff;18). Fokus ligger vid de vardagliga praktikerna och hur de mellanartsliga relationerna formar migranterna och deras livsstil. Samtidigt undersöks hur diskurser påverkar inflyttarnas rurala livsstilsmigration som kulturell föreställning och vardaglig praktik.

Materialet samlades in under fältarbeten på Gotland mellan hösten år 2017 och våren år 2019 och består av över 20 intervjuer och otaliga observationer. ${ }^{2}$ Intervjuer och observationer med sju personer framträder i artikeln. Detta material åskådliggör de centrala och återkommande dragen i det empiriska materialet såväl som de huvudsakliga analyserna (jfr Hansson 2019:13). Intervjuerna var i form av öppna samtal, i regel hemma hos flyttarna, där de fick berätta fritt om sin livsstilsförändring från stad till gotländsk landsbygd. ${ }^{3}$ Denna ostrukturerade och/eller semistrukturerade intervjuteknik öppnade upp för att synliggöra sådant som inte på förhand var påtänkt av mig som intervjuare (jfr Fägerborg 2011:98ff). Observationerna har framför allt gjorts vid besök hemma hos flyttarna medan de visat mig sina gårdar och vi tillsammans utfört olika gårdsrelaterade sysslor. Detta öppnade upp för att belysa och diskutera sidor av den rurala livsstilsmigrationen som inte framkom direkt i flyttarnas utsagor. Att vistas i gårdsmiljöerna och praktisera olika sysslor aktualiserade alltså nya infallsvinklar av det studerade fenomenet.

En annan insamlingsmetod som användes går ut på att själv leva delar av det vardagsliv som studeras (se Peker 2019b:19f). I mitt fall innebar det att jag under ett par veckor under sommaren 2018 själv lämnade mitt stadsliv för att bo på och ta ansvar för en informants gård med djur på Gotland. ${ }^{4}$ Gården bestod av boningshus, lador, växthus, hönshus och utedass. Medan flyttaren var bortrest levde jag delar av hennes vardagsliv och sysselsatte mig med de dagliga gårdsrelaterade praktikerna. Arbetet gick ut på att utfodra lamm, hästar, höns och katter. Jag borstade även hästarna, plockade ägg, 
hämtade vatten från en vattenkiosk och vattnade grödorna. Dagarna på gården dokumenterades genom kontinuerliga anteckningar i min fältdagbok. Genom att själv leva delar av det vardagsliv som studerades närmade jag mig flyttarnas vardag kroppsligt (jfr Frykman 2012:140), vilket fördjupade förståelsen av den rurala livsstilsmigrationen. ${ }^{5}$

I nästa avsnitt ges en kortfattad kontextualiserande beskrivning av migranternas motiv till flytten från stad till landsbygd. Detta följs av en diskussion om hur informanterna skaffar djur samt om socialiseringsprocesser som är förknippade med djuren och djurhållningen. Avsnittet därefter ger en övergripande skildring av flyttarnas vardagliga praktiker med djur. Denna analys fördjupas genom att problematisera värdekategoriseringar av djurarter, slakt samt köttätande inom ramen för informanternas rurala livsstilsmigration. Därefter analyseras djurhållningens övergripande betydelser för livsstilsmigrationen som pågående projekt. Avslutningsvis sammanfattas artikeln i sin helhet.

\section{Lämna staden för drömmen om landet}

Stress och utbrändhet är, som för många livsstilsmigranter, återkommande förklaringar i flyttarnas berättelser om varför de valde att lämna sin vardag i stadsmiljö (Amcoff 2000:102ff). Flyttarna talar även om hur de upplevde sina arbetsliv i staden som abstrakta och stundtals meningslösa. De saknade ofta en vardag med arbetsuppgifter och aktiviteter som upplevdes som konkreta med direkt synliga och meningsfulla resultat.

Varför sökte sig då flyttarna till just landsbygden? Det är tydligt att den förväntades utgöra en motpol till den vardag de hade i staden. Hos inflyttarna förknippades landsbygden med lugn, hälsa och idén om ett "äkta liv". Dessa föreställningar ligger i linje med idén om den rurala idyllen ${ }^{6}$. Denna bygger på föreställningar om landsbygden som en given tillflyktsort för ett enklare, mer autentiskt och lugnare liv. Landsbygden framställs även som traditionell och gammaldags i kontrast till staden som modern och förän- 
derlig. Dessa typer av landsbygdsföreställningar är inte endast ett samtida uttryck. Liknande associationer om livet på landsbygden återkommer i olika historiska sammanhang (Bergsten 1999:177ff; Lützen 2008:154ff; Löfgren 1979:63f). Ett exempel är den "gröna vågen" på 1970-talet som präglades av romantiska föreställningar om levnadssätt på landsbygden. I likhet med dagens rurala livsstilsmigranter motiverades motsvarande förflyttningar under "gröna vågen" ofta med idéer om landsbygden som en plats för ett äkta och naturnära liv (Ekberg 2016:16ff; Richardson 2000:1ff).

Flera informanter drömde om att etablera en livsstil med gård och djur. Inflyttaren Tomas som idag driver ett mindre lantbruk med bland annat får och hästar, berättar:

Jag har alltid varit intresserad av jordbruk. Jag har alltid varit intresserad av djur. Men lyckades aldrig övertyga mina föräldrar om det fiffiga $i$ att skaffa en bondgård och flytta från stan, vilket jag försökte länge. Jag tjatade på dem jämt, på pappa att han skulle bli bonde.

Tomas och flera av de andra flyttade alltså med den uttalade idén om att sköta om en gård med djur. Gården och djuren betraktades av dessa informanter som intimt förknippade med varandra. För de andra flyttarna var inte längtan efter att leva med djur lika uttalad. I själva verket framställs det ibland som att de inte riktigt vet varför de skaffade djur. Petra som idag bedriver fåravel uttrycker det såhär: "Sen har vi djur då, det är något som bara råkade bli". Hur Petra och några av de andra migranterna "blir med djur" eller likt Tomas etablerar djurhållning mer målmedvetet, diskuteras i följande avsnitt.

\section{Att skaffa eller bli med djur}

Det finns några mediala representationer som återkom ständigt $\mathrm{i}$ mina samtal med flyttarna. Det svenska TV-programmet "Mandelmanns gård", som handlar om familjen Mandelmann som lämnat Stockholm för att driva ett ekologiskt, självhushållande jordbruk på 
Österlen i södra Sverige, är ett av de mest återkommande exemplen. Ett annat är TV-programmet "Hundra procent bonde" (I Finland: "En tvättäkta lantis") som handlar om den danske självhushållande bonden Frank Erichsen och hans familj. Precis som flyttarna lämnade han storstaden till förmån för ett "nytt liv" på landsbygden. Dessa TV-program präglas av vackra idylliska gårdsmiljöer. De kommunicerar föreställningar om ett traditionellt, småskaligt och nostalgiskt lantbruk långt bort från modernitetens industriella metoder (jfr Backa 2019). På så vis reproducerar dessa mediala uttryck idéer om den rurala idyllen. I dessa program får dessutom djuren en väsentlig roll i den bemärkelse att en betydande del av programtiden ofta vigs åt djurrelaterade praktiker såsom utfodringar, äggplockning, mjölkning och lamning.

Flyttarna beskriver hur de beundrar TV-profilernas sätt att sköta sitt lantbruk, att de uppskattar de småskaliga och ekologiska odlingsmetoderna. Inte minst talar informanterna om djuren och djurhållningen som skildras i programmen, vilka typer av djur och raser de har, vilka foder de använder samt hur omsorgsfullt och vänskapligt TV-profilerna sköter om djuren. Det är uppenbart att dessa "kändissjälvhushållare" (se Backa 2019) är stora förebilder och inspirationskällor för den studerade gruppen. Sara som idag driver en gård med hästar, får, höns, katter och bin, berättar hur viktig bonden Frank var för henne som ny gårdsägare på Gotland: "I början var det verkligen såhär att man tittade på allt och satt på helspänn och tänkte, hur gör han, hur gör han?”. Hennes sätt att se upp till och försöka efterlikna livsstilen och djurskötseln som framställs i TV-programmen, återkommer hos så gott som alla inflyttare. Så som de berättar om kändissjälvhushållarna och deras påstådda livsstil, är det uppenbart att de fungerar som ett ideal för migranternas egna liv på den gotländska landsbygden. Kändissjälvhushållarna är således med och reproducerar diskurser om hur livet på landsbygden bör levas, vilket i sin tur formar flyttarnas praktiker och läroprocesser väl på plats. Informanterna identifierar sig dessutom med familjen Mandelmann och Frank Erichsen. Inflyttarna menar dels att de gör en "liknande resa" som TV-profilerna, men också att de själva fungerar som förebilder för andra som är intres- 
serade av denna typ av livsstilsförändring. På så vis är migranterna med och representerar samt reproducerar föreställningar om det goda livet på landsbygden.

Dessa mediala representationer är alltså en av förklaringarna till varför inflyttarna skaffar djur planerat, eller mer oplanerat "blir med djur". Med tanke på att informanterna ser upp till och eftersträvar den livsstil kändissjälvhushållarna representerar, och att djurhållningen har en tydlig roll i livsstilen, blir det i någon mån självklart att skaffa djur. Även om djurhållningen i sig inte var en målsättning för alla inflyttarna från början, är livsstilen de söker så intimt förknippad med djuren att det är svårt att praktisera den, såväl som att leva upp till förväntningarna om den, utan djurhållning. Detta visar alltså hur den rurala idyllen och de mediala uttrycken som är med och reproducerar densamma, påverkar handlingsutrymmet för vad det kan innebära att vara rural livsstilsmigrant. Diskurser internaliseras och praktiseras hos flyttarna allteftersom deras rurala livsstilsmigration fortskrider.

Gotland och dess förutsättningar har också betydelse för att migranterna börjar hålla djur. Flera av dem betraktade på förhand ön som en "djurvänlig plats", där det finns goda förutsättningar att hålla exempelvis hästar och får. Detta var också en av anledningarna till valet av Gotland som destination för den rurala livsstilsmigrationen.

Tina, som hade flera husdjur redan när hon bodde i Stockholms innerstad och nu har en gård med bland annat får, ankor, katter och hundar, berättar om hur hon ser på djurhållningen på ön: "Mitt djurhållande som jag hade i Stockholm med husdjur har jag alltid sett som lite knäppt, men här är det norm”. Flera av de andra flyttarna har liknande resonemang. Djurhållning upplevs som en norm på Gotland och dessutom som något man bör hålla på med som före detta stadsbo och inflyttad till den gotländska landsbygden. Migranterna berättar om hur grannar och andra i socknen kommit förbi och erbjudit dem som nyinflyttade att köpa, ta över eller byta till sig hönor, lamm, ankor och andra djur. På detta konkreta sätt kan alltså informanterna "bli med djur". 
De berättar även att djuren är ett vanligt samtalsämne bland grannar och andra i bygden. Djuren fungerar som en isbrytare för att bekanta sig med nya människor och blir således en social samlingspunkt (jfr Kulick 2017:368). Stig som är inriktad på hästskötsel berättar: "Man etablerar ju hästkontakt med dem som har hästar i närheten och gör saker och ting". Han och flera av de andra flyttarna vittnar på liknande sätt om hur skötseln av hästar, lamm och andra djur blir ett viktigt sätt att etablera kontakter och komma in i gemenskapen bland andra inflyttare, men även bland de som bott på ön i generationer (jfr Doré m.fl. 2019:17). I detta sammanhang utgör således djuren betydelsefulla resurser för att skapa gemenskap för livsstilsmigranterna (jfr Doré m.fl. 2019:7f).

Genom djuren och de sociala nätverken de skapar, ges också förutsättningar för ett kunskapsutbyte mellan nyinflyttade och etablerade, inte bara avseende djurhållningen i sig, utan även om gårdslivet och bygden i ett bredare perspektiv. Flyttarna lyfter också fram att djuren och djurhållningen blir ett sätt att befästa sin dedikation och seriositet när det kommer till den nya livsstilen. Tomas berättar: "Skaffar man djur, då är man inte här bara några månader. Djuren är på något sätt ett kvitto på varaktighet och långsiktighet". Att skaffa eller "bli med djur" blir således ett sätt för Tomas och de andra flyttarna att rota sig $i$ bygden och visa för omgivningen att de ämnar stanna. Djurhållningen blir alltså ett sätt att passa in på ön och i gruppen inflyttare, vilket uttrycks i deras socialiserings- och etableringsprocesser (se Peker 2019a:131ff). Detta visar hur informanternas rurala livsstilsmigration inte bara påverkas av olika typer av representationer av den rurala idyllen, utan också av de lokalt situerade praktikerna på den gotländska landsbygden.

Sammanfattningsvis har djuren och djurhållningen en mycket framträdande roll i den rurala idyll flyttarna söker. De längtar efter ett lugnare liv på landsbygden som ofta förväntas inkludera djur och djurhållning. Att informanterna aktivt skaffar eller bara "blir med djur" handlar bland annat om att kändissjälvhushållarna de ser upp till och förknippar sig med, är tydligt associerade med djurhållningspraktiker. Gotlands "djurvänliga" anseende gör dessutom 
att landsbygden på ön ligger i linje med dessa mediala representationer och således motsvarar den rurala idyll flyttarna sökte sig till. Att även de som inte planerat att skaffa djur, gör det väl på plats, kan delvis förklaras av djurens ställning på Gotland och i bilden av ön. De lokala socialiseringsprocesserna är också centrala faktorer för migranternas djurhållning. Att hålla djur ger gemenskap, sammanhang och tillhörighet på den gotländska landsbygden. Hur djurhållningen tar sig uttryck och vilka relationer som utvecklas till djuren i vardagen, undersöks i nästkommande avsnitt.

\section{Djur som vardag och vänner}

Det dagliga arbetet på gården jag tog hand om under sommaren år 2018 innefattade en rad olika djurrelaterade åtaganden. De flesta morgnar började med att jag utfordrade hästarna med kosttillskott och fyllde på de stora tunnorna med vatten. I samband med detta tittade jag även till fåren som delade hage med hästarna. Efter att jag sett att fåren också verkade må bra brukade jag gå över till hönshuset och titta till deras vatten och foder samt plocka ägg, som jag tillfälligt lade på en tunna tills att resten av sysslorna på gården var avklarade. Första ägget jag plockade var en stark personlig upplevelse som påminde mig om vad flera informanter berättat. Jag föreställde mig dock inte att det nyvärpta ägget skulle vara varmt. Känslan av det varma ägget i min hand blev en förkroppsligad erfarenhet. Att stryka handen över en hästkropp och känna dess muskelkraft, se ett får i ögonen, vakna till tuppen, få ont i kroppen av att bära tunga baljor med vatten eller få smuts under naglarna, är andra förkroppsligade praktiker och kunskapsprocesser som innebar att jag närmade mig migranternas upplevelser av djurhållningen. Genom att leva delar av det vardagsliv som studerades, skapades alltså förutsättningar för en fördjupad förståelse av flyttarnas rurala livsstilsmigration.

Alla informanter bedriver småskalig djurhållning där får, hästar och höns är vanligast. Några av flyttarna har också ankor, katter, hundar och biodling. I huvudsak producerar livsstilsmigranterna 
kött och ägg för eget bruk, där flera av dem är självförsörjande på dessa varor under delar av året. De ägnar även tid åt hantverksarbete där de tillverkar garn och fårskinnsprodukter. Ibland säljer informanterna vidare kött och andra produkter. Flera flyttare erbjuder också upplevelseaktiviteter såsom hästridning till turister under sommarmånaderna.

De vardagliga praktikerna med djuren uppskattas av informanterna eftersom de ger direkta, synliga och meningsfulla resultat. Detta ställer migranterna i kontrast till de abstrakta och till synes meningslösa sysslor som de menar ofta fyllde deras vardag i Stockholm. Det mest framträdande temat i flyttarnas berättelser om sin vardag med djur är dock hur de upplever att de utvecklat starka sociala band till sina djur. De pratar med dem, gosar med dem och betraktar dem i stor utsträckning som individer med personligheter. Djuren beskrivs genomgående som flyttarnas vänner. En viktig del av dessa upplevda vänskapsrelationer är känslor av välbefinnande, trygghet och lugn. Petra skildrar inlevelsefullt känslan av att borra näsan i fårens päls och känna den där speciella doften, som hon tycker så mycket om. Djuren älskar att bli kliade och kramade, förklarar Petra. Denna samvaro menar hon är både betryggande och helande: "Att vara nära ett djur, det är ju helt underbart", berättar Petra.

Flera av flyttarna beskriver likt henne hur samvaron med djuren har en slags terapeutisk verkan. Att umgås med djuren skapar sinnesfrid. Detta kan betraktas som en form av "husdjursterapi" (egen översättning), det vill säga att sällskap med djur används som en metod för återhämtning från ohälsa och för att uppnå generellt välbefinnande (Kulick 2017:364f). Den djurhållning informanterna bedriver kan alltså delvis ses som ett svar på och återhämtning från den ohälsa, i form av utbrändhet och stress, som de försökte lämna i staden. Djuren används på så vis som ett vardagligt verktyg för att realisera de hälsorelaterade önskningar som är förknippade med den rurala livsstilsmigrationen.

Även om flyttarna håller djur för kött-, skinn- och äggproduktion lyfts inte dessa verksamheter fram i våra samtal. De pratar i regel 
inte om hur mycket kött som framställs eller hur aveln organiseras. Istället är det de sociala dimensionerna som flyttarna självmant lyfter fram. Detta visar alltså att djurhållningen för dessa rurala livsstilmigranter till stor del är socialt och emotionellt motiverad.

\section{Får som sällskapsdjur?}

De vänskapliga relationerna till djuren gäller som jag gett exempel på inte bara de vanliga husdjuren hund och katt. Flera av flyttarna beskriver likt Petra ovan hur exempelvis fåren har en nära social betydelse. Hon får berätta vidare:

$\mathrm{Nu}$ förstår jag, det är så här de känner, alla de som har hundar. $\mathrm{Nu}$ har jag förstått vad de går igång på och vad det ger. Lamm är också väldigt tillgivna och väldigt tama och är nästan som hundar. De följer en och de kommer när man pratar.

Petra berättar vidare att hon är allergisk mot hundar och menar att hon därför aldrig utvecklat en nära relation till en hund. Istället har hon alltså fått, som hon ser det, oväntat nära relationer till sina får. Flera av flyttarna har liknande berättelser. De menar att de fått ompröva sina tidigare föreställningar om vilka relationer som en människa kan bygga till andra djurarter. Detta har påverkat hur de ser på människans och andra djurarters sociala ordning i förhållande till varandra. Samtidigt ger några migranter uttryck för en mer "traditionell" bild när det kommer till skillnader mellan olika djurarter (jfr Fitzgerald \& Taylor 2014:174f), där exempelvis hundar anses överordnade får avseende social status hos människan. Tomas berättar: "Hundarna är högst i den hierarkin om man ser det som en hierarki. Hundarna, katten och hästarna har samma nivå i vår familj”. Det är således tydligt att olika informanter ger samma djurarter skild social status.

Så gott som alla inflyttare beskriver hur de av olika anledningar fäster sig särskilt vid vissa individer, något som får betydelser för hur de värderar olika individer och djurarter i förhållande till varandra. När en tacka övergav sitt lamm fick Tomas och hans familj själva 
utfodra lammet. "Så hon har en speciell plats i våra hjärtan", konstaterar han. Detta gjorde alltså att familjen fick en starkare kontakt till just det lammet. Sara har fäst sig extra vid det första fåret hon skaffade sedan hon kom till Gotland. Det har utvecklats starka band mellan dem och många minnen från tiden då Sara levt på ön är förknippade med fåret. Tackan har fått följa med på Saras resa från nyinflyttad stockholmare, utan vana att driva lantbruk, till erfaren inflyttad med egen gård. Tina ger exempel på hur hon ser på sina mellanartsliga relationer:

Just nu har jag två hundar. Jag tycker om dem men det är inte själarnas förening. Jag vet inte om det är för att vi skaffade dem när vi hade små barn och man har andra saker som är en närmre. De är bara hundar i vår familj. [...] Jag var med när de första fåren föddes, man sitter uppe en hel natt och kämpar med att få i dem lite mjölk och bråkar med en dum tacka som inte vill dia. [...] Så ligger man där och gråter och svär under ett får en hel natt. Då kämpar man ju lite extra. Sen blir man så himla glad när de väl får börja äta och det blir liv. Det är ju helt fantastiskt.

Tina utvecklar resonemanget och beskriver hur hon inte har lika starka emotionella band till sina hundar som till sina får. Delvis har det att göra med att hon, likt Tomas ovan, varit med om en extraordinär situation med några specifika individer. Lamningen var dramatisk och stärkte banden till fåren. Någon motsvarig erfarenhet menar hon att hon inte delat med sina hundar. Tinas exempel ger också uttryck för det som Saras relation till sitt första får visar. De djur som tydligt relaterar till livsstilsmigrationen tillskrivs för många av informanterna större betydelse. Genom fårets ställning som symbol för Saras "nya liv", tillskrivs det en särskild emotionell roll. Fåret förkroppsligar Saras resa från stad till gotländsk landsbygd. Att Tina utvecklar starkare emotionella band till fåren som djurart, och att de överordnas hundarna i social betydelse i detta givna sammanhang, kan också förklaras med att fåren tillskrivs en större betydelse för de gårdsrelaterade praktiker som Tina förknippar med sin nya livsstil. 
Individualiseringsprocesser förstärker således informanternas band till vissa individer och djurarter. Detta gör i sin tur att flyttarna utifrån vardagliga praktiker och upplevelser på gården ständigt omförhandlar sina föreställningar om djurarters och enskilda individers förhållande till varandra (jfr Hagström 2014:142ff). Dessa omförhandlingar präglas av vad Doré m.fl. (2019) benämner som "ontologisk flexibilitet" (min översättning). De sociala banden till ett enskilt djur eller en djurart samt vilken roll dessa har i flyttarnas liv, förändras ständigt utifrån olika händelser och omständigheter (jfr Doré m.fl. 2019:9f). Kulturhistorikern Anne Katrine Gjerløff (2012) pekar på svårigheter att göra gränsdragningar mellan kategorier som sällskapsdjur och nyttodjur. Även om dessa kan framställas som varandras motsatser är det i själva verket flytande positioner som förändras i tid och rum (Gjerløff 2012:397ff). Denna flexibilitet präglar informanternas relationer till sina djur, genom att de utvecklar nära emotionella relationer till djurarter som de själva tidigare betraktat mer som "nyttodjur". I flyttarnas vardagliga praktiker kan också dessa djur få högre social status än "klassiska" sällskapsdjur. De mellanartsliga relationerna migranterna lever i kan alltså betraktas som okonventionella i den bemärkelse att de i vissa avseenden inte ger uttryck för eller praktiserar etablerade strukturer där särskilda djurarter är överordnade andra (jfr Charles \& Aull Davies 2011:78ff; Fitzgerald \& Taylor 2014:174f). Samtidigt går det att återfinna motsvarigheter till de flexibla positioneringar som präglar flyttarnas relationer i andra kulturella och historiska kontexter. Gjerløff pekar på hur synen på samma djurart varierat genom historien. I ett givet historiskt sammanhang har dessutom förståelsen av en djurart skiftat utifrån aspekter som klasstillhörighet, region samt mellan stadsbor och boende på landsbygd (Gjerløff 2012:397ff).

Så som flyttarna önskar leva sin rurala livsstil och de vardagliga praktiker som följer utav detta, skapar förutsättningar för nära sociala relationer med djuren. De praktiska erfarenheterna av djurhållningen och de emotionella band som utvecklas, förändrar sammanfattningsvis informanternas föreställningar om arthierarkier men också synen på enskilda djur. På så vis förändrar flyttarnas 
rurala livsstilsmigration deras mellanartsliga relationer såväl som deras föreställningar om dessa relationer.

\section{Att ha ihjäl sina vänner}

Inflyttarnas vänskapliga relationer till sina djur skapar utmaningar med tanke på att flera av djuren, förutom att vara vänner, samtidigt är "avsedda" för köttproduktion. Djurens mångbottnade roller aktualiseras tydligt när det är dags för slakt. Flyttarna tycker generellt att slakten både är känslomässigt påfrestande och sorglig, även om de inte utför slaktproceduren själva. Så här berättar Petra: "Det är inte lätt att djur ska slaktas. Det är inga lätta saker, det har jag väldigt mycket problem med". Harald som bedriver fåravel konstaterar: "Det finns något tungt $i$ att det snart är slut". Tina som vid intervjutillfället var relativt ny på ön och inte skickat några får på slakt ännu, bävar inför denna dag: "Man kan ju önska att slakten sker när man inte är hemma, att någon kommer och sköter den, men så enkelt är det ju inte. Jag måste väl fixa med transport och köra dem till slakteriet och höra dem ropa efter varandra”. Slakten kan också vara olika svår när det gäller skilda individer. Sara har skickat flera får till slakt, dock inte sitt första får som jag berättat om tidigare. Med tanke på deras starka relation har Sara valt att inte slakta fåret, detta är dock något hon planerar att göra så småningom. Förhållningsättet illustrerar flyttarnas generella synsätt på sina får, där de trots de mycket nära och vänskapliga relationerna, på lång sikt inte överväger att hålla fåren endast för sällskapets skull.

Så gott som alla informanter vittnar, på liknande sätt som exemplen ovan, om hur påfrestande slakten kan upplevas. Det småskaliga sätt som flyttarna bedriver djurhållning på, som i sig ger förutsättningar för nära och vänskapliga relationer med djuren, öppnar upp för tydliga emotionella utmaningar. Inflyttarnas strävan efter att sysselsätta sig med självhushållande praktiker, likt familjen Mandelmann och bonden Frank Erichsen, har alltså oundvikliga baksidor. Detta gör också att flera av migranterna, precis som Tina, hade föredragit 
att inte alls vara delaktiga i de moment som har med slakten att göra.

Hur hanterar då flyttarna dessa svåra delar av djurhållningen? Hur tacklar de det faktum att de ofta förstår sina djur som subjekt i bemärkelsen individer, men även som objekt i form av framtida köttprodukter (jfr Berglund 2006:113)? Flera av informanterna berättar för mig hur de utvecklat sätt att hantera det faktum att de "skickar sina vänner på slakt”. De försöker klippa de emotionella banden genom att umgås mindre med djuren när slakten närmar sig. Det kan handla om att sluta gosa med fåren som ska skickas på slakt eller inte spendera så mycket tid hos kycklingarna som vanligt. Här sker således en slags "främmandegörande process" där inflyttarna genom ändrade vanor och rörelsemönster på gården, distanserar sig från vänskapsrelationerna med djuren, som en metod för att underlätta den kommande exploateringen av dem (Maarbjerg 2015:103f). Tina har även en annan metod för att göra den stundande slakten mera uthärdlig:

Det ena är att vi har döpt alla handjuren till Ben. Så de heter Ben Jackson, Ben Thomson, alla har namn som börjar på Ben. Ben heter de för att i [land] på [språk] $]^{7}$ betyder ben mat. Så det har varit det första steget att alla heter mat.

Tina berättar alltså hur hennes får som ska slaktas får tillägget "mat" till sina personliga namn, ett får som heter Jackson blir inför slakt Mat-Jackson. Etnologen Sara Berglund (2006) diskuterar hur namn är ett sätt att individualisera djur, att göra dem till subjekt. Samtidigt pekar hon på hur olika typer av djur namngivs på skilda sätt. Djur som betraktas som sällskapsdjur, såsom hundar, får i regel personliga namn. Djur som oftare kategoriseras som nyttodjur, som exempelvis får, ges istället beskrivande namn utifrån utseende eller andra egenskaper (Berglund 2006:157ff). I detta sammanhang blir det således tydligt hur Tina och de andra informanterna med liknande strategier använder namn och namngivning för att hantera relationen till djuren såväl som det faktum att de ska slaktas. Tinas får har, i likhet med andra migranters, personliga namn vilket vittnar om att djuren i regel betraktas som individer med egna 
personligheter. När väl slakten stundar ges dock Tinas får mera beskrivande namn genom tillägget "mat", en tydlig markering om djurens kommande öde. Detta blir ett sätt att göra fåren mer till objekt. De dubbelnamn som djuren ges symboliserar flyttarnas relationer till djuren när slakten närmar sig. Fåren är både vänner och framtida kött, både subjekt och objekt.

\section{Att äta sina vänner}

Det är inte bara slakten som upplevs som utmanande för inflyttarna i deras livsstil med djur på den gotländska landsbygden. De har också fått svårigheter att äta kött efter att de flyttat till ön. En förklaring till detta som de ger uttryck för, är att de som forna stadsbor inte hunnit vänja sig vid tanken att de lever med djur som sedan slaktas och äts i form av kött. Tina uttrycker det som att "flera nya problem uppkommer som inte fanns i Stockholm", i och med att "man inte är van vid att känna sin mat". För att hantera svårigheterna med sitt köttätande utvecklar informanterna olika strategier och förhållningssätt. Tina berättar vidare:

Jag är född och uppvuxen i Stockholm. Jag är van vid att köpa kött i plastpaket utan namn och ansikte. Förra året hade vi mycket ankor, så vi fick slakta dem. Första ankan vi slaktade, den blev aldrig uppäten, den ligger kvar i frysen. Sen slaktade vi 25 ankor och så packade jag allting i plast, vakuumförpackade och frös in. Då blev det plötsligt jättelätt att använda det. Då var det lite som att gå till butiken, det är anonymt.

När Tina slaktade sin första anka lades den hel i frysen. Att se hela djurkroppen och på det viset göra det mer påtagligt att den har varit ett liv och att det funnits en social relation mellan henne och djuret, gjorde det alltför svårt för Tina att hantera och äta köttet från ankan. För de övriga ankornas del valde hon därför att stycka upp kropparna i mindre bitar och paketera kroppsdelarna som om de vore köpta i en mataffär. Flera inflyttare berättar om liknande strategier och praktiska knep för att hantera det svåra i att äta det egenproducerade köttet. Förhållningssätten anknyter till den dis- 
kussion som etnologen Maria Maarbjerg (2015) för om hur närvarande djuret är när konsumenter handlar och äter kött. Maarbjerg menar att köttindustrin tillämpar en så kallad "kött som ingrediens"-strategi (egen översättning), vilken går ut på att minska närvaron av djuret vid försäljning av kött. Istället för att göra det tydligt att köttet kommer från en varelse som levt, framställs produkten som "vilken ingrediens som helst", för att på så vis minska riskerna för att konsumenten ska känna dåligt samvete och/eller ifrågasätta sitt köttätande (Maarbjerg 2015:101ff). Etnologen Michell Zethson (f.d. Göransson) (2019) skriver om liknande transformationsprocesser där djuret "döljs" bland annat genom paketering. I dessa processer går det från att vara djur till att bli ett "råmaterial" (Zethson 2019:209;218f). Samtidigt pekar hon på en språklig dimension i försöken att göra djurkroppen frånvarande i köttet. Genom att använda icke-kroppsliga ord som mat, pålägg och korv blir djur mindre synliga i försäljningen och ätandet av djurkroppar (Göransson 2017:19).

Flera av livsstilsmigranterna praktiserar alltså dessa typer av transformationsprocesser. När Tina väljer att paketera köttet från sina ankor i plastförpackningar är det ett sätt att tona ned djurets närvaro i köttet. Istället för att lägga det i frysen i formen av en hel ankkropp, paketeras det så att det framstår som "vilken ingrediens som helst" eller ett "råmaterial". Att hon, som diskuterats i föregående avsnitt, börjar benämna sina djur som "mat", kan med avstamp i Zethsons resonemang även betraktas som en språklig transformationsprocess. Tina använder alltså det generella ordet "mat" för att tona ner att det i själva verket handlar om en djurkropp. Dessa olika praktiker gör att det blir lättare att förbise att köttet varit ett liv, ett liv som det dessutom funnits en social relation till.

Trots att inflyttarna ofta finner svårigheter med att äta det egenproducerade köttet och av denna anledning skapar strategier för att minska djurets närvaro, framställs det inte som en lösning att köpa kött i butik. Även om de inte haft en social relation till de djur som säljs i form av kött i butik, har de genom kroppsliga erfarenheter av att leva med djur som blir mat i form av kött, utvecklat en generell 
svårighet med sitt köttätande. Köttet i butiken väcker känslor och påminner om att djuren varit liv, men också om de sociala relationer flyttarna har till sina egna djur på gården. Även om informanterna upplever svårigheter med att äta kött generellt, menar de samtidigt att det egenproducerade köttet är bättre än mycket annat, med tanke på att de kunnat garantera att djuren fått ett bra liv. Petra berättar:

Det viktiga är att de har ett så bra liv som möjligt så länge de finns här. [...] Är det något som man ska äta så är det lamm, eftersom de har ett så underbart liv. De går ute och bara har det bra, äter varierat, massa goda örter, blad och gräs.

Här lyfter Petra, i likhet med flera inflyttare, fram djurens goda och "naturliga" levnadsvillkor. Det är kött som producerats på detta sätt som migranterna föredrar att äta. Dessa typer av förhållningssätt relaterar till det Zethson (2019) beskriver som "nykarnivora rörelser", inom vilka djuret inte göms utan snarare lyfts fram i konsumtionen av köttprodukter. Fokus läggs vid att lyfta fram respekt för djuren genom att bland annat påpeka den omsorgsfulla, "lantliga" och "naturliga" djurhållningen, vilket dessutom sätts i en motsatsrelation till industriell köttproduktion (Zethson 2019:214f). Detta relaterar även till vad Maarbjerg kallar en "kött som djur"-strategi (egen översättning), som likt det Zethson beskriver, handlar om att lyfta fram djuret vid köttförsäljning genom att skildra den goda djurhållningen (2015:101ff). När inflyttarna likt Petra ovan berättar om hur gott liv djuren har och hur "naturlig" djurhållningen är, praktiserar de dessa typer av "kött som djur"-strategier. Detta anknyter även till idén om "glatt kött", det vill säga att köttet, utöver att det framställts med större hänsyn till djuren, också är godare att äta (Zethson 2018:252f; Fitzgerald \& Taylor 2014:170ff). Förutom att fåren haft ett "underbart liv" så som Petra beskriver det, berättar många av inflyttarna om hur gott köttet blir tack vare sådan djurhållning. Det finns således en instrumentell dimension med den omsorgsfulla och naturliga djurhållningen (jfr Fitzgerald \& Taylor 2014:177f). Djuren i sin roll som flyttarnas vänner bör ha god livskvalitet samtidigt som detta är ett sätt för migranterna att producera 
välsmakande kött. Slutligen finns en tendens bland flera inflyttare att använda vetskapen om att djuren haft ett bra liv, som ett sätt att legitimera sitt köttätande. Berättelsen om den goda djurhållningen fungerar som en "samvetsdetox" (Zethson 2019:221), det vill säga att informanterna både för sig själva och inför mig bygger upp föreställningar om ett moraliskt försvarbart köttätande.

Även om livsstilsmigranterna menar att de utvecklat oväntat nära relationer till djur de tidigare i huvudsak betraktat som nyttodjur, har detta inte förändrat synen på vilka djur som är tänkbara att äta. Göransson beskriver att det i en samtida västerländsk kontext är otänkbart att ha nära relationer till en hund och samtidigt konsumera hundkött. I regel görs det nämligen en skarp distinktion mellan "sällskapsdjur" och "köttdjur" (Göransson 2017:166). Flyttarnas djurhållning präglas inte av en sådan distinktion då de trots de vänskapliga relationerna med fåren skickar dem till slakt och äter köttet från deras kroppar. Samtidigt diskuterar inga av migranterna att det skulle vara tänkbart att exempelvis börja äta hästkött, även om relationerna till fåren i vissa fall kan vara starkare än de till hästarna. Dessa gränsdragningar framstår således som kulturellt cementerade i bemärkelsen att flyttarnas pågående omförhandlingar av sina mellanartsliga relationer inte verkar beröra vilka djurarter som är ätbara. Den kulturella förståelsen av får som en djurart "avsedd" för köttproduktion ifrågasätts alltså inte.

För att sammanfatta diskussionen om djurrelaterade vardagliga praktiker och mellanartsliga relationer som levs mellan flyttare och djur är det tydligt att den rurala livsstilsmigrationen förändrat informanternas föreställningar om djur och djurhållning. Migranterna utvecklar ofta nära sociala relationer till djuren. I berättelserna framstår dessa relationer oftast som överordnade de produkter som skapas genom djurhållningen. Trots att en viktig del av flyttarnas rurala livsstilsmigration handlar om att hålla djur likt kändissjälvhushållarna, är det inte produkterna som framställs som hamnar i fokus i samtalen, utan snarare djuren som levande individer. De nära sociala relationerna utvecklas även till de djur som ofta inte betraktas som sällskapsdjur. På så vis förändrar den rurala livs- 
stilsmigrationen inflyttarnas förståelse av hierarkier djurarter och djurindivider emellan. Som ett resultat av de nära sociala relationerna med djuren känner migranterna ett stort emotionellt motstånd till slakten. Den givna förutsättning som slakten innebär för möjligheten att självhushålla, blir väl på plats och i kontakt med djuren, utmanande att praktisera. Att informanterna väljer att hålla djur för köttproduktion, trots att det är så emotionellt utmanande, visar sammantaget hur förankrade flyttarna är i diskurserna om vad livet som rural livsstilsmigrant innebär. Att hålla djur utan självhushållande ambitioner blir ett alltför tydligt avsteg från den livsstil flyttarna söker sig till på den gotländska landsbygden. Inflyttarnas rurala livsstilsmigration har också förändrat deras syn på köttätande i sig, även om bilden av vilka djurarter som betraktas som ätbara framstår som tämligen oföränderlig. Inom dessa skilda områden har alltså livsstilsmigranternas flytt från stad till gotländsk landsbygd och deras nya vardagliga praktiker, haft flera konsekvenser för deras relationer till djur. Dessa relationer präglas sammanfattningsvis av mångsidighet och komplexitet, vilka är typiska för människors relationer till andra djur (Charles \& Aull Davies 2011:72f). Flyttarna tar hand om sina djur och utvecklar starka emotionella band. Som ett led i livsstilen och målsättningen om egenproducerad mat exploateras samtidigt djurens kroppar på olika sätt. Här framstår alltså livsstilen informanterna söker som överordnad relationerna till djuren och deras rätt till liv. Hur djuren och djurhållningen påverkar livsstilsmigrationen som självförverkligande livsstilsprojekt, sammanfattas i nästa avsnitt.

\section{Torkan och en äventyrad livsstil}

Jag har sju hästar nu, har varit åtta. Femton tackor, två baggar, tjugofem lammungar. Jag får vara glad om jag får behålla tre hästar, kanske två. Allt annat måste bort.

Under sommaren år 2018 drabbades Gotland mycket hårt av den omfattande torkan som pågick i Europa (Länsstyrelsen i Gotlands län). Charlotte berättar ovan om hur hon kommer att tvingas 
nödslakta de flesta av sina djur på grund av foderbristen som torkan orsakat. Flera av flyttarna riskerar på liknande sätt att behöva avveckla hela sin djurhållning på grund av torkans konsekvenser. De äventyrar således informanternas möjligheter att kunna hålla djur. Detta medför att flera av flyttarna omprövar sin rurala livsstilsmigration. Tina berättar:

Man kan inte köpa hö och i de mörkaste stunder landar man någonstans i att, om man inte ens får hö till fåren, inte kan ha kvar ett enda djur, utan måste slakta allihop, då vet jag inte om jag vill bo kvar.

Flera av informanterna överväger likt Tina att flytta om de inte skulle kunna fortsätta med djurhållningen. Med tanke på att torkan hotar djurhållningen, hotar den också den livsstil flyttarna etablerat. Kulturgeografen Michael Woods (2011) diskuterar hur centrala djuren kan vara för djurbönders "lifescape", det vill säga det kulturella och sociala samspel som finns mellan människa och landskap. Tvingas bönderna göra sig av med djuren försvinner också en del av deras "lifescape" och den mening som är förknippad med platsen (Woods 2011:214ff). Detta är tydligt hos inflyttarna. Den mening som är förknippad med platsen och den livsstil de etablerat på Gotland, är på många sätt beroende av djurhållningen. Försvinner möjligheten att hålla djur tappar också platsen och gården i någon mån sin mening eftersom de meningsskapande praktikerna med djurhållningen uteblir. De identitetsskapande processerna som är förknippade med den rurala idyll informanterna söker sig till och de ideal de försöker efterleva förutsätter också djurhållning. Djuren är alltså med och skapar de livsvärldar som präglar inflyttarna (jfr Hagström 2014:142), vilket gör att de inte kan vara de rurala livsstilsmigranter de önskar om djuren försvinner.

Livsstilsmigration är som fenomen pågående och i ständig utvärdering av migranterna (Benson \& O’Reilly 2009a:2; Benson \& O'Reilly 2009b:615f). Detta är tydligt hos den studerade gruppen. I samband med utmaningar funderar flyttarna återigen på att byta boendemiljö och livsstil. Även de som bott på ön under flera års tid, bildat familj och etablerat sig i övrigt resonerar på detta sätt. 
Torkan och risken att leva utan djur skildrar således den ständiga utvärdering som präglar informanternas rurala livsstilsmigration som pågående självförverkligande projekt.

\section{Avslutning}

I denna artikel har djurs och djurhållningars betydelser för rural livsstilsmigration analyserats. Materialet visar att mellanartsliga relationer kan vara centrala för dessa typer av migrationsprocesser. Valet av destination för migrationen, flyttarnas etableringsprocesser såväl som deras vardagliga meningsskapande praktiker väl på plats, kretsar i någon mån kring djur och djurhållning. Genom att betrakta rural livsstilsmigration med avstamp i mellanartsliga relationer har således nya infallsvinklar på mänskliga förflyttningsmönster uppenbarats. Samtidigt har studiet av den rurala livsstilsmigrationen möjliggjort fördjupad förståelse av mellanartsliga relationer. Flytten aktualiserar nämligen flera komplexa processer avseende människors relationer till andra djur. Migrationen åskådliggör människors ambivalenta förhållningssätt till andra djur samt hur mellanartsliga relationer präglas av ständiga omförhandlingar, som i sig är avhängiga människors intressen såväl som vardagliga omständigheter. Den rurala livsstilsmigrationen skildrar också hur diskurser och normer formar flyttarnas mellanartsliga relationer, där vissa aspekter av djurhållningen framstår som mer omförhandlingsbara än andra. Sammanfattningsvis visar flyttarnas berättelser att djuren och de djurrelaterade praktikerna är avgörande för den livsstil informanterna söker, det vardagsliv de etablerar såväl som för migrationsprojektet i sin helhet.

\section{Käll- och litteraturförteckning}

\section{Intervjuer}

Charlotte, 27.7.2018, längd: 1h50min.

Harald, 1.10.2018, längd: 3h1min. 
Petra, 4.10.2018, längd: 1h53min.

Sara, 8.12.2017, längd: $1 \mathrm{~h} 38 \mathrm{~min}$.

Stig, 2.10.2018, längd: 1h52min.

Tina, 4.10.2018, längd: $2 \mathrm{~h} 8 \mathrm{~min}$.

Tomas, 2.8.2018, längd: 2h35min.

Samtliga intervjuer utförda av författaren.

Samtliga intervjuer förvaras hos författaren.

\section{Observationer}

Observationer på informants gård, på besök hos andra informanter och på övriga platser är utförda mellan december år 2017 och mars år 2019.

Samtliga observationer utförda av författaren.

Samtliga observationsanteckningar förvaras hos författaren.

\section{Litteratur}

Agnidakis, Paul 2013. Rätten till platsen. Tillhörighet och samhörighet $i$ två lokala industrisamhällen under omvandling. Höör: Brutus Östlings Bokförlag Symposion.

Amcoff, Jan 2000. Samtida bosättning på svensk landsbygd. Uppsala: Uppsala universitet.

Backa, Andreas 2019. Husbehovsodlingens epistemiska gemenskap - från hobbyodling till självhushållning. Laboratorium för folk och kultur: https://bragelaboratorium.com/2019/12/09/ husbehovsodlingens-epistemiska-gemenskap-fran-hobbyodling-tillsjalvhushallning/ (Hämtad 19.2.2020).

Benson, Michaela \& O'Reilly, Karen 2009a. Lifestyle Migration: Escaping to the Good Life? Lifestyle Migration: Expectations, Aspirations and Experiences, (red.) Michaela Benson \& Karen O’Reilly. Farnham: Ashgate.

Benson, Michaela \& O Reilly, Karen 2009b. Migration and the search for a better way of life: a critical exploration of lifestyle migration. The Sociological Review, 57(4):608-621.

Berglund, Sara 2006. Vägen till vinnarcirkeln: travhästen och dess människor mellan sport och spel. Lund: Lunds universitet. 
Bergsten, Magnus 1999. Bonden i bladet. Svenskt bondeliv: livsform och yrke, (red.) Anders Salomonsson. Lund: Studentlitteratur.

Birke, Lynda \& Latimer, Joanna 2009. Natural relations: horses, knowledge, technology. The Sociological Review, 57(1):1-27.

Charles, Nickie \& Aull Davies, Charlotte 2011. My Family and Other Animals: Pets as a Kin". Human and Other Animals, (red.) Bob Carter \& Nickie Charles. London: Palgrave Macmillan.

Doré, Antoine; Michalon, Jérôme \& Monteiro, Teresa Líbano 2019. The Place and Effect of Animals in Families. Enfances Familles Générations, 32(2019).

Ekberg, Kristoffer 2016. Mellan flykt och förändring: utopiskt platsskapande i 1970-talets alternative miljö. Lund: Lunds universitet. Fitzgerald, Amy J. \& Taylor, Nik 2014. The cultural hegemony of meat and the animal industrial complex. The Rise of Critical Animal Studies: From the Margins to the Centre, (red.) Nik Taylor \& Richard Twine. Abingdon-on-Thames: Routledge.

Frykman, Jonas 2012. Berörd: plats, kropp och ting i fenomenologisk kulturanalys. Stockholm: Carlsson.

Fägerborg, Eva 2011. Intervjuer. Etnologiskt fältarbete, (red.) Lars Kaijser \& Magnus Öhlander. Lund: Studentlitteratur.

Gjerløff, Anne Katrine 2012. Offer, Fjende, Frænde, Føde. Historisk tidskrift, 132(3):392-422.

Göransson, Michell 2017. Ätbara andra. Göteborg: Makadam förlag. Hagström, Erica 2014. En pedagogisk relation mellan människa och häst. På väg mot en pedagogisk filosofisk utforskning av mellanrummet. Pedagogisk forskning i Sverige, 19(2-3):132-152.

Hansson, Kristoffer 2019. Kroppen och den motsägelsefulla staden. Kulturanalytiska perspektiv på funktionshinder och urbana rum. Budkavlen, 98:9-37.

Haraway, Donna Jeanne 2008. When Species Meet. Minneapolis: University of Minnesota Press. Elektronisk resurs tillgänglig via ProQuest Ebook Central, 5 augusti 2020.

Hoey, Brian A. 2009. Pursuing the Good Life: American Narratives of Travel and a Search for Refuge. Lifestyle Migration: Expectations, Aspirations and Experiences, (red.) Michaela Benson \& Karen $\mathrm{O}$ 'Reilly. Farnham: Ashgate. 
Ingold, Tim 2013. Prospect. Biosocial Becomings. Integrating Social and Biological Anthropology, (red.) Tim Ingold \& Gisli Palsson. Cambridge: Cambridge University Press.

Korpela, Mari 2019. Searching for a countercultural life abroad: neo-nomadism, lifestyle mobility or bohemian lifestyle migration? Journal of Ethnic and Migration Studies, DOI: 10.1080/1369183X.2019.1569505.

Kulick, Don 2017. Human-Animal Communication. Annual Review of Anthropology, 46:357-378.

Lützen, Karin 2008. De gode gamle dage ude på landet. Folk Og Kultur, årbog for Dansk Etnologi Og Folkmindevidenskab, 37(1):154-164.

Länsstyrelsen i Gotlands län: https://www.lansstyrelsen.se/ download/18.4df86bcd164893b7cd949fac/1536319094024/

Regeringsbrev.\%20Gotländska\%20konsekvenser\%20av\%20torkan\%20 2018.pdf (Hämtad 18.2.2020).

Löfgren, Orvar 1984. Våra vänner i naturen. Den dolda historien: 27 uppsatser om vårt okända förflutna, (red.) Ronny Ambjörnsson \& David Gaunt. Stockholm: Författarförlaget.

Löfgren, Orvar 1979. Människan i naturen. Den kultiverade människan, (red.) Jonas Frykman \& Orvar Löfgren. Malmö: Gleerups.

Maarbjerg, Maria 2015. Smagen af koliv med udsigt. En udforskning af dyret i kødet. Kulturstudier, 6(1):100-120.

Nilsson, Gabriella 2013. Breaking Free and Settling Down. Contradictory Cultural Meaning of Rural Retirement Migration among Swedish Seniors. Nordic Seniors on the Move. Mobility and Migration in Later Life, (red.) Anne Leonora Blaakilde, Gabriella Nilsson. Lund: Lund universitet.

Osbaldiston, Nick 2011. The Authentic Place in the Amenity Migration Discourse. Space and Culture, 14(2):214-226.

Palmgren, Ann-Charlotte 2011. Autoetnografi. Etnografiska hållplatser (red.) Kerstin Gunnemark. Lund: Studentlitteratur.

Peker, Gurbet 2019a. Att göra Gotland till sin hembygd. Från Gutabygd: årsskrift för den gotländska hembygdsrörelsen, (red.) Annika Melin. Visby: Gotlands Hembygdsförbunds förlag.

Peker, Gurbet 2019b. Landsbygd i nöd och lust. En etnologisk studie av livsstilsmigration till Gotland. Uppsala: Uppsala universitet. 
Richardson, Heidi 2000. Tilbake til jorda: drømmer og hverdagsliv. Bergen: Bergen universitet.

Ulver, Sofia 2012. Den nygröna människan. En översikt av landsbygdens status i förändring. Jordbruksverket.

Vetenskapsrådet. Forskningsetiska principer. http://www.codex.vr.se/ texts/HSFR.pdf (Hämtad 19.2.2020).

Woods, Michael 2011. Rural. London: Routledge.

Woube, Annie 2014. Finding One's Place: An Ethnological Study of Belonging among Swedish Migrants on the Costa del Sol in Spain. Uppsala: Uppsala universitet.

Zethson, Michell 2019. Köttslöjd: Diffraktioner på temat nykarnism \& ätna djur. RIG, 101(4):209-223.

Zethson, Michell 2018. Pre rigor mortis. Djur: Berörande möten och kulturella smärtpunkter, (red.) Simon Ekström \& Lars Kaijser.

Göteborg: Makadam förlag.

\section{Noter}

1 Deltagarna i denna studie benämns som "flyttare", "inflyttare", "migrant", "livsstilsmigrant" och "informant". De har alla flyttat från Stockholmsområdet till den gotländska landsbygden (ett område utanför tätort enligt SCB:s definitioner). Flyttarna är mellan 35 och 70 år gamla. Gruppen består av något fler kvinnor än män. De flesta har bosatt sig på ön under de senaste tio åren medan några har bott på Gotland betydligt längre. Inga har bott permanent på Gotland tidigare. Informanterna försörjer sig inte enbart på gårdsverksamheten utan har även andra sysselsättningar.

2 Delar av detta material användes också inom ramen för min masteruppsats.

3 Samtalen spelades in och inspelningarna transkriberades. För att skapa läsvänlighet har vissa upprepningar, utfyllnadsord och stakningar uteslutits.

4 Metoden är inte direkt autoetnografisk (se Palmgren 2011:173ff) då jag varken tillhör den grupp som studeras eller avsåg göra en motsvarande flytt från stad till landsbygd.

5 Forskningen som bedrivits inom ramen för denna artikel följer svenska Vetenskapsrådets forskningsetiska principer för humanistisk-samhällsvetenskaplig forskning (Vetenskapsrådet 2020). Namnen på personerna och djuren som presenteras i artikeln är fingerade. Andra detaljer som uppenbart riskerar att avslöja informanternas identitet utelämnas. Att leva delar av vardagslivet som studerades medförde etiska överväganden. Det innebar ett stort ansvar att ta hand om en gård med djur. För att säkerställa att djuren och gården i övrigt ombesörjdes, fick jag en grundlig genomgång av sysslorna som förväntades av mig samt kontaktuppgifter 
till personer i närheten som kunde hjälpa till vid behov. Ett annat etiskt övervägande som aktualiserades var hur jag som forskare skulle hantera det faktum att jag levde i en informants boningshus och hade direkt tillgång till hennes hem utan hennes närvaro. För att hantera detta samtalade jag med informanten om att delar av hennes liv skulle vara föremål för observation. Även om hon samtyckte till detta har jag kontinuerligt uteslutit detaljer i materialet som skulle kunna riskera att exponera privata uppgifter om personen i fråga.

6 I detta sammanhang återfinns några olika benämningar för att beskriva liknande typer av föreställningar om landsbygden. "Torparromantik" (Löfgren 1979:63f) och "pastorala myten" (Amcoff 2000:103) är några exempel. I artikeln används genomgående benämningen "rural idyll".

7 Av anonymiseringsskäl är fårens namn utbytta samt land och språk borttaget. 


\section{Animals and Rural Lifestyle Migration}

\section{Gurbet Peker}

Keywords: Lifestyle migration, rural idyll, animal husbandry, interspecies relationships

This article examines the role of animals and animal husbandry in rural lifestyle migration to the Gotlandic countryside. One area of interest is the significance of animals and animal husbandry as part of migrants' notions of the rural idyll and the place they seek. The article also describes and analyses animal-related everyday practices and interspecies relationships that are developed between migrants and animals.

The empirical material has been collected using ethnographic methods based on observations and qualitative interviews. The researcher also emerged herself in aspects of the rural lifestyle migration being studied. The informants have all left the city of Stockholm in favour of life in the Gotlandic countryside, where they devote themselves to small-scale animal husbandry and keep sheep, horses, chickens and other animals.

The theoretical foundation is that humans and other animals are in a state of constant becoming-with and, thus, create each other's lifeworlds. The focus is on analysing everyday practices and how interspecies relationships shape the migrants and their lifestyles. At the same time, the researcher also looks at the way in which discourses affect the migrants' rural lifestyle migration, both as cultural preconceptions and everyday practices.

The results show that animals and animal husbandry play a central role in the rural idyll and the place that migrants seek. The interspecies relationships are also important for the informants' socialisation and establishment processes in the Gotlandic countryside. The migrants find their relationships with the animals meaningful and crucial for the established lifestyle. These close everyday relationships lead the informants to renegotiate aspects of their view of animals as well as their view of eating meat. This lifestyle with animals also involves emotional challenges related to slaughter, an aspect of animal husbandry that the migrants find stressful. The interspecies relationships documented in the material are consistently characterised by ambivalence and constant renegotiations. In summary, the article shows that the animals and the animal-related practices are 
Peker

crucial for the lifestyle to which the migrants aspire, the everyday life they establish, as well as for the migration project as a whole. 